E Q U I L I B R I U M

2 ( 5 ) 2010

ISSN 1689-765X

Ewa Malinowska

\title{
Using the Concept of the Weighted Ishikawa Diagram for Defining the Impact of Catering Enterprises on the Environment
}

Key words: Ishikawa Diagram, environmental load, institutional food service unit

\begin{abstract}
Every organization uses various resources to achieve its aim. Some of resources come from the environment, for example, energy carriers, or water. As a result of an organization's activity, some pollution is emitted to the water and atmosphere. Presently in Poland there can be observed a high growth rate of services in the field of institutional food service. It is a legal obligation in Poland to implement and maintain a institutional food safety system, as the HACCAP (HACCP - Hazard Analysis and Critical Control Points). The organizations that have implemented HACCP into their operations cause environmental loads that have negative impact on the environment. Taking into account the above-mentioned issue, the article attempts to answer the question: which environmental aspect, closely connected with the maintenance of the HACCP system in an institutional food service unit, have the largest impact on the pollution of the environment? The weighted Cause and Effect Ishikawa Diagram is used as a research tool to achieve this target. Its modification that is presented in scientific literature enables us to display both qualitative and quantitative information. In accordance with this method, 'critical paths' are indicated for the most important causes that create the given effect. What is defined in this article as the effect is generating of environmental loads on the environment by an institutional food service unit. While the causes are defined as environmental aspects, they characterize this organizational part of the unit that is covered by the institutional food safety system. They include water consumption, municipal wastes generation, and consumption of energy carriers: natural gas and electric energy, inorganic waste generation, cleaning supply measures consumption, the consumption of the office materials and exploitation materials to office equipment. The analysis of the quantity of particular factors that create environmental aspects show which environmental aspects have the largest impact on the environment and cause its pollution. These are as follows: water consumption, cleaning supply measures consumption and electric energy consumption.
\end{abstract}

\section{INTRODUCTION}

The world's dynamic economic development which took place in the previous century caused the creation of the concept of the new social and economic order, 
based on a sustainable development. The concept was to ensure the next generations a civilisation development in harmony with the environment. In order to fulfil the tasks of eco-development a continuous attention should be paid to the coexistence and co-dependence of human beings, economy and natural environment.

Functioning of every organisation to a greater or a lesser extent is related to environmental pollution. Even if an enterprise does not realise its harmful influence on the environment, as a consequence of its activity, certain amounts of contaminants are emitted to the air, water, and soil. Every organisation makes use of energy carriers and uses water. Usage of these environmental aspects ${ }^{1}$ affects the impoverishment of the natural environment.

Nowadays, in Poland, a quick rate of growth of one form of service activity is observed - catering. Catering enterprises, besides others whose aim is production or turnover of foodstuffs, are obliged by the Polish law to implement and effectively maintain the HACCP system whose target is to protect consumers against threats which he can meet in contact with foodstuff.

Functioning of an organisation in a system ensuring the foodstuff and feeding safety is not indifferent for the environment. However, companies encompassed with this system do not pay attention to the fact to what degree their activity, in the light of the law in force, affects the generation of environmental burden which has a negative impact on the natural environment. That is why this study undertakes the attempt of defining which of the environmental aspects related strictly to maintenance of the HACCP system in a catering enterprise affects the burdening of the environment with contaminants, to the greatest extent. In order to define the aspects' importance the method presented in literature as the weighted cause-result Ishikawa graph (Gwiazda, 2005) was applied. The examination encompassed the catering division in one of the primary schools in Gdynia. The choice of such a type of a catering unit was dictated by the easiness of getting in touch with the personnel and the financial transparency of the local government entity. This made it easier to obtain cost and reckoning information which was indispensable for carrying the examination out.

\section{ENVIRONMENTAL ASPECTS IN THE HACCP SYSTEM}

The basic document telling about feeding safety is the Act on Food and Feeding Safety $^{2}$, which imposes the obligation of applying the system whose acronym is HACCP everywhere where the contact with foodstuff takes place. According to the Act, the HACCP system is the system of Hazard Analysis and Critical Control

${ }^{1}$ Environmental aspect - an element of the activity of an organisation or its products or services which may interact with the environment. PN-EN ISO 14001:2005.

${ }^{2}$ Act of Food and Feeding Safety of 25 August, 2006 (O. J. of 27 September, 2006). 
Points. It consists in procedures which aim at ensuring food safety by means of identification and assessment of the threat scale - from the point of view of food health requirements and of the risk of threats appearing in the course of all food production and turnover stages. This system also aims at defining the methods of elimination or reduction of threats and at defining correction activities.

In order that the HACCP system could function, the conditions encompassed by the GMP (Good Management Practice) and GHP (Good Hygienic Practice) should be implemented earlier. These systems define a number of factors which must be fulfilled in order to ensure safety in meals production - in the case of the examined entities.

Concordantly to the GMP and GHP, the entities ought to have a proper functional layout of rooms with detached 'clean' and 'dirty' zones, with a proper number of refrigerating and heating appliances. Equipment in the feeding division (shelves, cupboards, racks) must be adapted to rapid and efficient cleaning. The entity has to be equipped also with such a number of sink chambers that the process of meat, fruit, and vegetable preliminary treatment were not crossing with each other. It is also required that in the premises where it is necessary, the sink with hot and cold water for hands washing was mounted.

The GHP requires that all appliances and furniture were kept in impeccable cleanliness. It is recommended that washing and disinfection processes should be carried out by means of special chemical agents for food industry. Appropriate equipment for washing and disinfection of premises, apparatuses and equipment should be supplied. In the catering entity there should be separated, independent rooms for washing cooking dishes as well as table dishes. The dish washing room should possess equipment for scalding and drying of the washed dishes. Monitoring organs recommend installing of special appliances (electrical grinders for organic waste) which grind the remains of food products carefully, directing them to the sewage system.

In the catering entities an efficient system of removing non-organic waste should function. Waste and garbage should be collected in defined places out of the premises in which food is stored, and they should be systematically removed according to a fixed schedule.

In order to implement the HACCP system in the entity, an appropriate documentation should be created and kept. The documentation should confirm the activities proving correct way of the entity organisation and the correct way of the employees' conduct (Wiśniewska, 2005).

In result of the necessity of maintaining a properly functioning HACCP system in the catering entities, the following environmental aspects can be identified: water consumption, production of sewage, consumption of energy carriers: electrical power and natural gas, non-organic waste production, usage of office and exploitation materials for the office equipment as well as consumption of cleaning agents. 


\section{THE CONCEPT OF ISHIKAWA WEIGHTED DIAGRAM}

The Cause-effect Ishikawa graph may be applied for identification of any phenomena in various life spheres. It is the tool used in order to represent relationships between given results and their potential reasons. The graph is based on main reasons, from which detailed reasons stem, in such a way that the graph picture represents a fishbone. Ishikawa graph is most often used for analysis of production processes. According to literature (Łuczak, Matuszak-Flejszman, 2007; Żuchowski, Łagowski, 2004; Wolniak, Skotnicka, 2008) this method is based on the analysis of main reasons: $5 \mathrm{Ms}$ - method, machine, material, man, management. In the $5 \mathrm{M}+1 \mathrm{E}$ variant, additional environment-related reasons are considered, in $7 \mathrm{Ms}$ - with measurement, and in $8 \mathrm{Ms}$ - finances. The Ishikawa diagram may be constructed by a group of people in result of brain-storming, or as a result of individual work of people who have an appropriate experience and knowledge.

A traditional Ishikawa graph is a tree showing links between analysed reasons, and their hierarchy. It presents a group of reasons but does not define their impact on the analysed problem. The idea of Ishikawa weighted graph is based on the presentation of qualitative information pertaining to the examined problem and on the quantity analysis which decides about the importance of individual reasons on the background of the remaining ones. In the case of a traditional graph, in order to point out the most or the least important reason, an analysis and group discussion is to be carried out. The concept of the weighted cause-effect graph liquidates such a need and allows avoiding a great subjectivity in the assessment of the impact of particular reasons or sub-reasons (Gwiazda, 2005).

Methodology of elaboration of the weighted Ishikawa graph encompasses realisation of tasks which consist in defining the set of main reasons and groups of sub-reasons for every main reason, then in fixing their weights when using the method of comparison by pairs. The final phase is fixing the absolute values of sub-reasons' weights which define the degree of their importance in the background of the remaining sub-reasons. This makes it possible to identify those factors whose share in the creation of the examined result is the greatest.

The study applies the concept of the weighted Ishikawa graph for identification of factors which have a considerable impact on arising environmental burdens which contribute to the deepening of the environment pollution degree. As the main reasons, the environmental aspects identified earlier were presented, whereas the groups of sub-reasons constitute the activities which cause arising of aspects. All these activities are strictly related to maintenance of the feeding safety in a catering entity. 


\section{RESEARCH RESULTS}

As it has already been mentioned, the main reasons in the examined case are identified environmental aspects. Importance indicators of every of the main reasons were defined with the method of comparison by pairs (Tab.1). Comparisons pertained to a one-month period.

When comparing by pairs the rule was applied that the factors composing one of the aspects appear (are used) in a greater amount, the analysed aspect received the 0.75 value, whereas the other one -0.25 . If (the appearance) usage of factors composing two aspects appears on the same level, the values equal to 0.5 were ascribed. If, however, the usage of the factors of one aspect, when compared with the other one, did not take place, then it would receive the value equal to 0 , the one would receive 1 . The work, however, did not note such a case. The comparisons excluded those fields in Table 1 in which the same aspects cross. The comparison process run as follows: the particular environmental aspects from column one where compared with individual aspect from columns two to seven. For instance, in the field on crossing of the second line and column seven the value of 0.75 was inserted, which means that monthly water consumption in the examined case is relatively higher than the consumption of office materials, whereas in the field on the crossing of line seven and column two the value of 0.25 is inserted. This denotes a reverse situation: consumption of office materials in the examined month was relatively smaller than water consumption.

Table 1. Matrix comparisons of reasons

\begin{tabular}{|c|c|c|c|c|c|c|c|c|c|}
\hline & 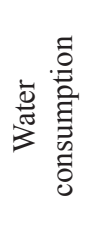 & 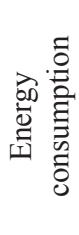 & 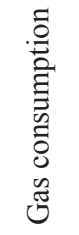 & 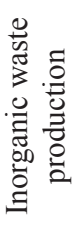 & 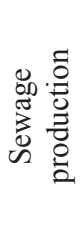 & 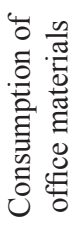 & 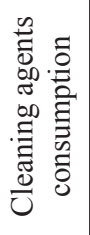 & $\Sigma$ & $\Sigma_{\mathrm{n}}$ \\
\hline Water consumption & $\mathrm{x}$ & 0.5 & 0.75 & 0.75 & 0.5 & 0.75 & 0.5 & 3.75 & 0.18 \\
\hline Energy consumption & 0.5 & $\mathrm{x}$ & 0.75 & 0.75 & 0.5 & 0.75 & 0.5 & 3.75 & 0.18 \\
\hline Gas consumption & 0.25 & 0.25 & $\mathrm{x}$ & 0.5 & 0.25 & 0.5 & 0.25 & 2 & 0.10 \\
\hline $\begin{array}{l}\text { Inorganic waste } \\
\text { production }\end{array}$ & 0.25 & 0.25 & 0.5 & $\mathrm{x}$ & 0.5 & 0.25 & 0.25 & 2 & 0.10 \\
\hline Sewage production & 0.5 & 0.5 & 0.75 & 0.5 & $\mathrm{x}$ & 0.75 & 0.5 & 3.5 & 0.17 \\
\hline $\begin{array}{l}\text { Consumption of of- } \\
\text { fice materials }\end{array}$ & 0.25 & 0.25 & 0.5 & 0.75 & 0.25 & $\mathrm{x}$ & 0.25 & 2.25 & 0.11 \\
\hline $\begin{array}{l}\text { Cleaning agents } \\
\text { consumption }\end{array}$ & 0.5 & 0.5 & 0.75 & 0.75 & 0.5 & 0.75 & $\mathrm{x}$ & 3.75 & 0.18 \\
\hline
\end{tabular}

Source: own study. 
As a result of dividing the particular weights (Table 1, column 9) by their sum, the normalised weights of the main reasons were received - relative weights. It turned out that the factors creating the following environmental aspects were produced in the greatest amounts: water and electrical power consumption and usage of cleaning agents. Each of the mentioned aspects influences the occurrence of the examined result in the proportion of $18 \%$.

Table 2. Matrix comparisons of environmental aspects and stage process

\begin{tabular}{|c|c|c|c|c|c|}
\hline $\begin{array}{c}\text { Stage process } \\
\text { Environmental aspects }\end{array}$ & $\begin{array}{c}\text { Storage } \\
\text { of raw } \\
\text { materials }\end{array}$ & $\begin{array}{l}\text { Prelimi- } \\
\text { nary } \\
\text { treatment }\end{array}$ & $\begin{array}{l}\text { Thermal } \\
\text { treatment }\end{array}$ & $\begin{array}{l}\text { Meals } \\
\text { distribu- } \\
\text { tion }\end{array}$ & $\begin{array}{l}\text { Cleanli- } \\
\text { ness } \\
\text { mainte- } \\
\text { nance }\end{array}$ \\
\hline Water consumption & $\mathrm{x}$ & $\mathrm{x}$ & $\mathrm{x}$ & & $\mathrm{x}$ \\
\hline Energy consumption & $\mathrm{x}$ & $\mathrm{x}$ & $\mathrm{x}$ & $\mathrm{x}$ & \\
\hline Cleaning agents consumption & $\mathrm{x}$ & $\mathrm{x}$ & $\mathrm{x}$ & & $\mathrm{x}$ \\
\hline Sewage production & $x$ & $\mathrm{x}$ & $\mathrm{x}$ & & $x$ \\
\hline
\end{tabular}

Source: own study.

The next task of the described concept is defining the set of sub-reasons for each of the main reasons and fixing their relative weights within the limits of a given reason. As presented in Table 1, the weights of main reasons constitute two groups. Environmental aspects which received weights equal to 0.18 and 0.17 may be included in one group and in the second group are those whose usage or production is insignificant (weights equal to 0.10 and 0.11 ). As a result of the source material analysis presenting the volumes of usage of factors generating aspects of the second group, it has been stated that they have an insignificant share in triggering the environmental burdens, and sub-reasons for these aspects were not analysed.

In order to define sub-reasons for the remaining main reasons, the limits of the examined process were delineated and phases whose organisation of activities had the impact on the problem examined in this research (creation of environmental aspects) were itemised. The process commences with storage of raw materials and finishes with the phase of meals distribution. Between the phases mentioned above there are: the phase of raw material preliminary treatment (washing, peeling, grinding), thermal treatment (cooking, frying, baking, stewing), whereas the activities included in the phase of cleanliness maintenance continue throughout the whole process (dishes, appliances and premises washing and disinfection as well as hygiene of persons taking part in the process). On the basis of correlations presented in Table 2, the sub-reasons for each of the main reasons were defined, and their identification is included in Table 3. 
Table 3. Identification of sub-reasons

\begin{tabular}{|c|c|}
\hline Main reason & Sub-reason \\
\hline \multirow{5}{*}{$\begin{array}{l}\text { 1. Water } \\
\text { consumption }\end{array}$} & 1.1. necessary for keeping cleanliness in the warehouses \\
\hline & 1.2. necessary for meals preparation \\
\hline & 1.3. necessary for keeping personal hygiene of the staff \\
\hline & 1.4. necessary for keeping cleanliness of the production premises \\
\hline & 1.5. necessary for keeping cleanliness in the dish-washing rooms \\
\hline \multirow{5}{*}{$\begin{array}{l}\text { 2. Energy } \\
\text { consumption }\end{array}$} & $\begin{array}{l}\text { 2.1. necessary for maintenance of work of refrigerating (warehousing) } \\
\text { equipment }\end{array}$ \\
\hline & $\begin{array}{l}\text { 2.2. necessary for maintenance of work of tiny gastronomy machines } \\
\text { and appliances (grinders, mixers, cutting machines) }\end{array}$ \\
\hline & $\begin{array}{l}\text { 2.3. necessary for maintenance of work of big gastronomy machines and } \\
\text { appliances (heating stools, frying pans, stoves) }\end{array}$ \\
\hline & $\begin{array}{l}\text { 2.4. necessary for maintenance of work of dish-washers and scalding } \\
\text { machines }\end{array}$ \\
\hline & 2.5. necessary for maintenance of work of heating counters \\
\hline \multirow{4}{*}{$\begin{array}{l}\text { 3. Cleaning agents } \\
\text { consumption }\end{array}$} & 3.1. necessary for keeping cleanliness in the warehouses \\
\hline & $\begin{array}{l}\text { 3.2. necessary for maintenance of cleanliness in the so called 'clean } \\
\text { production premises' }\end{array}$ \\
\hline & $\begin{array}{l}\text { 3.3. necessary for maintenance of cleanliness in the dish- washing } \\
\text { rooms }\end{array}$ \\
\hline & 3.4. necessary for maintenance of the staff personal hygiene \\
\hline \multirow{4}{*}{$\begin{array}{l}\text { 4. Sewage } \\
\text { production }\end{array}$} & 4.1. in result of keeping cleanliness in the warehouses \\
\hline & 4.2. in result of keeping cleanliness in production premises \\
\hline & 4.3. in result of keeping cleanliness in dish-washing room \\
\hline & 4.4. in result of keeping personal hygiene of staff \\
\hline
\end{tabular}

Source: own study.

Procedure of fixing relative weights of sub-reasons within individual main reasons consists also in comparing by pairs. In Tables 4 and 5 the comparison results which were achieved after the analysis of source materials between particular activities which cause the occurrence of environmental aspects were presented.

The comparative analysis carried out for the 'water consumption' aspect shows that the greatest consumption of this resource is caused by keeping cleanliness in the production premises - the preliminary treatment room, kitchen and giving out room. At the end of the working day, all the machines, appliances, kitchen working tops, floors and walls must be absolutely clean. Next activity 
Table 4. Matrix comparisons of sub-reasons: water and energy consumption

\begin{tabular}{|c|c|c|c|c|c|c|c|c|c|c|c|c|c|c|c|}
\hline & 1.1. & 1.2. & 1.3. & 1.4. & 1.5. & $\Sigma$ & $\Sigma_{\mathrm{n}}$ & & 2.1. & 2.2. & 2.3. & 2.4 & 2.5. & $\Sigma$ & $\Sigma_{\mathrm{n}}$ \\
\hline 1.1. & $\mathrm{x}$ & 0.25 & 0.5 & 0.25 & 0.25 & 1.25 & 0.125 & 2.1. & $\mathrm{x}$ & 0.75 & 0.5 & 0.5 & 0.75 & 2.5 & 0.250 \\
\hline 1.2. & 0.75 & $\mathrm{x}$ & 0.75 & 0.5 & 0.5 & 2.5 & 0.250 & 2.2. & 0.25 & $\mathrm{x}$ & 0.25 & 0.25 & 0.5 & 1.25 & 0.125 \\
\hline 1.3. & 0.5 & 0.25 & $\mathrm{x}$ & 0.25 & 0.25 & 1.25 & 0.125 & 2.3. & 0.5 & 0.75 & $\mathrm{x}$ & 0.5 & 0.75 & 2.5 & 0.250 \\
\hline 1.4. & 0.75 & 0.5 & 0.75 & $\mathrm{x}$ & 0.75 & 2.75 & 0.275 & 2.4. & 0.5 & 0.75 & 0.5 & $\mathrm{x}$ & 0.75 & 2.5 & 0.250 \\
\hline 1.5. & 0.75 & 0.5 & 0.75 & 0.25 & $\mathrm{x}$ & 2.25 & 0.225 & 2.5. & 0.25 & 0.5 & 0.25 & 0.25 & $\mathrm{x}$ & 1.25 & 0.125 \\
\hline
\end{tabular}

Source: own study.

resulting in vast water consumption is the meals preparation process, i.e., washing of food raw materials, adding water during the thermal treatment. On the third place, as far as water consumption is regarded, there is the work in the dish washing room. Water is indispensable here for the dish-washer as well as for the waste grinder which may function only when the water is continuously flowing. Smaller water consumption was observed when cleaning the storage-rooms which are being washed less frequently than the kitchen as well as for personnel's hygienic purposes.

Table 5. Matrix comparisons of sub-reasons: cleaning agents consumption and sewage production

\begin{tabular}{|c|c|c|c|c|c|c|c|c|c|c|c|c|c|}
\hline & 3.1. & 3.2. & 3.3. & 3.4. & $\Sigma$ & $\Sigma_{\mathrm{n}}$ & & 4.1. & 4.2. & 4.3. & 4.4. & $\Sigma$ & $\Sigma_{\mathrm{n}}$ \\
\hline 3.1. & $\mathrm{x}$ & 0.25 & 0.25 & 0.5 & 1.00 & 0.167 & 4.1. & $\mathrm{x}$ & 0.25 & 0.25 & 0.5 & 1 & 0.167 \\
\hline 3.2. & 0.75 & $\mathrm{x}$ & 0.5 & 0.75 & 2.00 & 0.333 & 4.2. & 0.75 & $\mathrm{x}$ & 0.25 & 0.75 & 1.75 & 0.292 \\
\hline 3.3. & 0.75 & 0.5 & $\mathrm{x}$ & 0.75 & 2.00 & 0.333 & 4.3. & 0.75 & 0.75 & $\mathrm{x}$ & 0.75 & 2.25 & 0.375 \\
\hline 3.4. & 0.5 & 0.25 & 0.25 & $\mathrm{x}$ & 1.00 & 0.167 & 4.4. & 0.5 & 0.25 & 0.25 & $\mathrm{x}$ & 1 & 0.167 \\
\hline
\end{tabular}

Source: own study.

The volume of electrical power consumption was estimated on the basis of energy-intensity of individual devices. The greatest energy consumption was registered when storing raw materials and samples of prepared dishes. This result is generated to a great extent by the number of refrigerating and freezing appliances and the continuity of their work. Also, considerable volume of electrical power consumption is observed when the dish-washers and so called big kitchen equipment (frying pans, stoves, and convection furnaces) are working. Lesser consumption takes place in the case of heating counters and tiny kitchen equipment which work periodically.

The amounts of the consumption of cleaning agents and of sewage production are strictly related to the amount of water used. And similarly as in the case of describing the factors affecting the 'water consumption' aspect - in the case of factors influencing the size of environmental aspects presented in Table 5, the 
main influence follows from the activities related to keeping cleanliness in production and in the dish washing rooms. Analysing the aspect of 'sewage production', one must notice that the greatest weight was ascribed to the 'keeping cleanliness in the dish washing room' sub-reason. It is influenced to a great extent by the food-waste grinding device.

Table 6. Absolute weights

\begin{tabular}{|c|c|c|c|c|}
\hline \multirow{2}{*}{ Reason } & \multirow{2}{*}{ Relative weights } & \multirow{2}{*}{ Sub-reason } & \multirow{2}{*}{ Weights } & Relative \\
\hline & & & & Absolute \\
\hline \multirow{10}{*}{ 1. Water consumption } & \multirow{10}{*}{0.18} & \multirow{2}{*}{1.1} & & 0.125 \\
\hline & & & & 0.023 \\
\hline & & \multirow{2}{*}{1.2} & & 0.250 \\
\hline & & & & 0.045 \\
\hline & & \multirow{2}{*}{1.3} & & 0.125 \\
\hline & & & & 0.023 \\
\hline & & \multirow{2}{*}{1.4} & & 0.275 \\
\hline & & & & 0.050 \\
\hline & & \multirow{2}{*}{1.5} & & 0.225 \\
\hline & & & & 0.041 \\
\hline
\end{tabular}

Source: own study based on Gwiazda, 2005.

Table 7. Analysis of the results obtained from the Ishikawa diagram

\begin{tabular}{|l|l|c|c|c|c|}
\hline \multicolumn{2}{|c|}{ Sub-reason } & $\begin{array}{c}\text { Relative } \\
\text { weights }\end{array}$ & $\begin{array}{c}\text { Absolute } \\
\text { weights }\end{array}$ & $\begin{array}{c}\text { Cumula- } \\
\text { absolute } \\
\text { weights } \\
\text { 4ive \% } \\
\text { absolute } \\
\text { weights }\end{array}$ \\
\hline 3.3. & $\begin{array}{l}\text { Sewage production in result of keep- } \\
\text { ing cleanliness in dish-washing room }\end{array}$ & 0.375 & 0.064 & 8.98 & 8.98 \\
\hline $\begin{array}{l}\text { Cleaning agents consumption neces- } \\
\text { sary for maintenance of cleanliness } \\
\text { in the so called "clean production } \\
\text { premises" }\end{array}$ & 0.333 & 0.060 & 8.44 & 17.42 \\
\hline 3.3. & $\begin{array}{l}\text { Cleaning agents consumption neces- } \\
\text { sary for maintenance of cleanliness in } \\
\text { the dish- washing rooms }\end{array}$ & 0.333 & 0.060 & 8.44 & 25.86 \\
\hline 4.2. & $\begin{array}{l}\text { Sewage production in result of keep- } \\
\text { ing cleanliness in production premises }\end{array}$ & 0.292 & 0.050 & 6.99 & 32.85 \\
\hline
\end{tabular}


Table 7 - continued

\begin{tabular}{|c|c|c|c|c|c|}
\hline & Sub-reason & $\begin{array}{l}\text { Relative } \\
\text { weights }\end{array}$ & $\begin{array}{l}\text { Absolute } \\
\text { weights }\end{array}$ & $\begin{array}{l}\% \\
\text { absolute } \\
\text { weights }\end{array}$ & $\begin{array}{l}\text { Cumula- } \\
\text { tive } \% \\
\text { absolute }\end{array}$ \\
\hline 1.4 . & $\begin{array}{l}\text { Water consumption necessary for } \\
\text { keeping cleanliness of the production } \\
\text { premises }\end{array}$ & 0.275 & 0.050 & 6.97 & 39.82 \\
\hline 1.2 . & $\begin{array}{l}\text { Water consumption necessary for } \\
\text { meals preparation }\end{array}$ & 0.250 & 0.045 & 6.34 & 46.15 \\
\hline 2.1 . & $\begin{array}{l}\text { Energy consumption necessary for } \\
\text { maintenance of work of refrigerating } \\
\text { (warehousing) equipment }\end{array}$ & 0.250 & 0.045 & 6.34 & 52.49 \\
\hline 2.3 . & $\begin{array}{l}\text { Energy consumption necessary for } \\
\text { maintenance of work of big gastrono- } \\
\text { my machines and appliances (heating } \\
\text { stools, frying pans, stoves) }\end{array}$ & 0.250 & 0.045 & 6.34 & 58.83 \\
\hline 2.4 . & $\begin{array}{l}\text { Energy consumption necessary for } \\
\text { maintenance of work of dish-washers } \\
\text { and scalding machines }\end{array}$ & 0.250 & 0.045 & 6.34 & 65.16 \\
\hline 1.5 . & $\begin{array}{l}\text { Water consumption necessary for } \\
\text { keeping cleanliness in the dish-wash- } \\
\text { ing rooms }\end{array}$ & 0.225 & 0.041 & 5.70 & 70.87 \\
\hline 3.1 . & $\begin{array}{l}\text { Cleaning agents consumption neces- } \\
\text { sary for keeping cleanliness in the } \\
\text { warehouses }\end{array}$ & 0.167 & 0.030 & 4.23 & 75.10 \\
\hline 3.4 . & $\begin{array}{l}\text { Cleaning agents consumption neces- } \\
\text { sary for maintenance of the staff } \\
\text { personal hygiene }\end{array}$ & 0.167 & 0.030 & 4.23 & 79.33 \\
\hline 4.1. & $\begin{array}{l}\text { Sewage production in result of keep- } \\
\text { ing cleanliness in the warehouses }\end{array}$ & 0.167 & 0.028 & 4.00 & 83.33 \\
\hline 4.4 . & $\begin{array}{l}\text { Sewage production in result of keep- } \\
\text { ing personal hygiene of staff }\end{array}$ & 0.167 & 0.028 & 4.00 & 87.33 \\
\hline 1.3 . & $\begin{array}{l}\text { Water consumption necessary for } \\
\text { keeping personal hygiene of the staff }\end{array}$ & 0.125 & 0.023 & 3.17 & 90.50 \\
\hline
\end{tabular}


Table 7 - continued

\begin{tabular}{|l|l|c|c|c|c|}
\hline \multicolumn{2}{|c|}{ Sub-reason } & Relative \\
weights & $\begin{array}{c}\text { Absolute } \\
\text { weights }\end{array}$ & $\begin{array}{c}\% \\
\text { obsolute } \\
\text { weights }\end{array}$ & $\begin{array}{c}\text { Cumula- } \\
\text { tive \% } \\
\text { absolute } \\
\text { weights }\end{array}$ \\
\hline 2.2. & $\begin{array}{l}\text { Energy consumption necessary for } \\
\text { maintenance of work of tiny gastrono- } \\
\text { my machines and appliances (grind- } \\
\text { ers, mixers, cutting machines) }\end{array}$ & 0.125 & 0.023 & 3.17 & 93.66 \\
\hline 2.5. & $\begin{array}{l}\text { Energy consumption necessary for } \\
\text { maintenance of work of heating } \\
\text { counters }\end{array}$ & 0.125 & 0.023 & 3.17 & 96.83 \\
\hline 1.1. & $\begin{array}{l}\text { Water consumption necessary for } \\
\text { keeping cleanliness in the warehouses }\end{array}$ & 0.125 & 0.023 & 3.17 & 100.00 \\
\hline
\end{tabular}

Source: own study.

Relative weights reflect the values in relation to a given level (of main reasons or sub-reasons). Hence, the 0.18 weight defines that the 'water consumption' reason constitutes $18 \%$ of the results generated by all main reasons. By analogy, the 0.275 weight defines over $27 \%$ of share of the 1.3 sub-reason as a result of the 'water consumption' reason. After calculating the weight for main reasons and sub-reasons, the next step is the calculation of absolute weights, it means such which represent the hierarchy of individual weights in relation to the whole graph. Absolute weights for individual sub-reasons are calculated by means of multiplying relative weights of sub-reasons and of proper main reasons (Table 6).

The last phase of the described concept is the analysis of the weighted Ishikawa graph, on the basis of absolute values of the received weights. Based on the analyses presented in the work, it appears 'sewage production' activity has the greatest share in generating the environmental charges which arise as $\mathrm{s}$ result of keeping cleanliness in the dish washing room. The lowest share is constituted equally by four factors: consumption of water for the purpose of personal hygiene, keeping cleanliness in the warehouses, and electrical power consumption for maintaining the work of small kitchen equipment and of heating counters. Using the Pareto-Lorenz rule, the factors which burden the environment to a great degree were isolated (Table 7). A simplified weighted Ishikawa graph with the group of key sub-reasons is presented in Figure 1. 
Figure 1. Simplified weighted Ishikawa graph

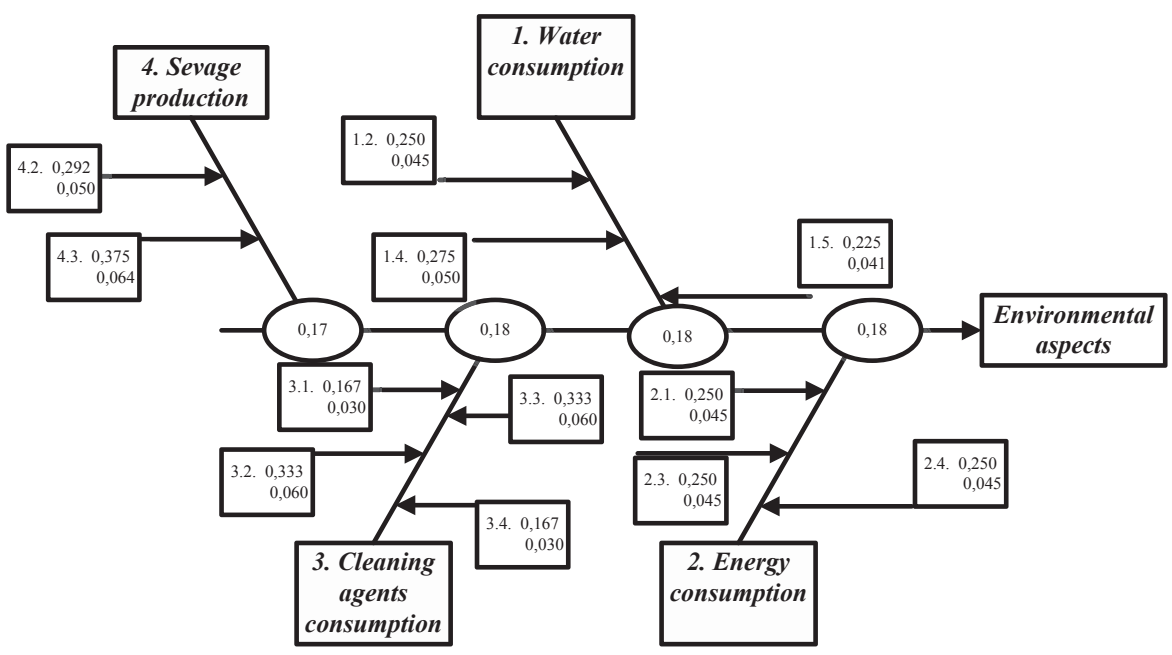

Source: own study.

\section{Conclusion}

Organisations carrying out their activity encounter many problems. In order to prevent them, or in order to have the opportunity of undertaking corrective activities, one should learn what the reasons of the occurrence of such problems are. This purpose may be dealt with the Ishikawa graph which also helps to order the obtained reasons of the considered problem.

As a result of broadening the possibilities available in the traditional Ishikawa graph by means of introduction of weights of individual reasons and sub-reasons, it is possible to present key indicators which generate the analysed problem. The found factor does not have to be included in the group of main reasons only. It is recommended to find more detailed reasons - by means of fixing absolute weights. It allows a deeper analysis of the studied problem together with pointing out the most essential sub-reasons. The example of the application of the weighted Ishikawa graph for isolation of key factors which influence the generation of environmental burdens as a result of the functioning of the HACCP system, shows the possibilities of taking advantage of this tool.

It is self-evident that the activity of catering enterprises may not be realised without using the aspects examined in this work. Energy, water and consumption of cleaning agents as well as sewage production are related to the specificity of work of these organisations. However, it should be considered whether 
modern solutions which can contribute to restricting of the usage of factors constituting particular aspects may be applied. The results of the examination carried out, the defined critical factors in particular, may initiate a broader discussion of this topic.

\title{
REFERENCES
}

Gwiazda A., (2005), Koncepcja ważonego wykresu Ishikawy, „Problemy Jakości”, no. 4.

Łuczak J., Matuszak-Flejszman A., (2007), Metody i techniki zarzqdzania jakościa. Kompendium wiedzy, Wydawnictwo Quality Progress, Poznań.

Wiśniewska M., (2005), Od gospodarstwa do stołu. Organizacja i zarzqdzanie jakościq oraz bezpieczeństwem produktu żywnościowego, Wydawnictwo UG, Gdańsk.

Wolniak R., Skotnicka B., (2008), Metody i narzędzia zarzq̨dzania jakościq. Teoria i prakty$k a$, Wydawnictwo Politechniki Śląskiej, Gliwice.

Żuchowski J., Łagowski E., (2004), Narzędzia i metody doskonalenia jakości, Wydawnictwo Politechniki Radomskiej, Radom.

\section{WYKORZYSTANIE KONCEPCJI WAŻONEGO WYKRESU ISHIKAWY DO OKREŚLENIA WPEYWU DZIALALNOŚCI ZAKŁADÓW ŻYWIENIA ZBIOROWEGO NA ŚRODOWISKO NATURALNE}

\section{Słowa kluczowe: wykres Ishikawy, obciqżenia środowiskowe, zakłady żywienia zbiorowego}

\begin{abstract}
Abstrakt: Każda organizacja do osiągnięcia postawionego przez siebie celu wykorzystuje różnego rodzaju zasoby. Wśród nich są również zasoby zaczerpnięte z naturalnego środowiska, np. nośniki energetyczne czy woda. W wyniku prowadzonej przez organizację działalności, do powietrza, wody, czy gleby odprowadzane są pewne ilości zanieczyszczeń.

Obecnie w Polsce obserwuje się szybkie tempo wzrostu jednej z form działalności usługowej - żywienia zbiorowego, która, z uwagi na obowiązujące w Polsce przepisy, jest zobligowana do wdrożenia i utrzymania systemu zapewnienia bezpieczeństwa żywnościowego (HACCP). Również i zakłady żywienia zbiorowego przyczyniają się do tworzenia obciążeń środowiskowych, które negatywnie wpływają na stan środowiska przyrodniczego. Z uwagi na powyższe, w pracy podjęto próbę odpowiedzi na pytanie, jaki aspekt środowiskowy, ściśle związany z utrzymaniem systemu HACCP w placówce żywienia zbiorowego, w największym stopniu wpływa na obciążenie środowiska naturalnego zanieczyszczeniami. Do tego celu wykorzystano ważony diagram przyczynowo-skutkowy Ishikawy. Jako skutek w pracy określono tworzenie przez zakład żywienia zbiorowego obciążeń środowiskowych, wpływających na zanieczyszczenie środowiska naturalnego, natomiast przyczynami są zidentyfikowane aspekty środowiskowe, charakteryzujące tę część organizacyjną jednostki, która objęta jest systemem zapewnienia bezpieczeństwa żywności i żywienia. W wyniku analizy wielkości poszczególnych czynników, tworzących aspekty środowiskowe, przyczyniającymi się do zanieczyszczenia środowiska w największym stopniu okazały się następujące aspekty - przyczyny główne: zużycie wody, zużycie środków czystości oraz zużycie energii elektrycznej. Natomiast spośród analizowanych podprzyczyn największy udział w tworzeniu obciążeń środowiskowych ma wytwarzanie ścieków komunalnych powstałych w wyniku utrzymania czystości w zmywalni.
\end{abstract}


